\title{
DESKRIPSI EFEK SAMPING OBAT ANTI TB PADA PASIEN TB YANG SEDANG MENJALANI PENGOBATAN TB DI PUSKESMAS HARAPAN RAYA PEKANBARU
}

\author{
Tri Siwi KN ${ }^{1}$, Mailur Rahmi ${ }^{2}$ \\ ${ }^{1,2}$ Prodi Keperawatan, FMIPA \& Kesehatan, Universitas Muhammadiyah Riau, Jl. Tuanku \\ Tambusai No 02 Pekanbaru \\ Email : trisiwi@umri.ac.id
}

\begin{abstract}
ABSTRAK
Penyakit Tuberkulosis (TB) adalah penyakit menular yang harus mendapatkan pengobatan khusus dengan antibiotik yang diberikan minimal selama 6 bulan. Penggunaan obat anti TB dengan berbagai jenis obat dan durasi yang lama bisa menimbulkan keluhan efek samping obat. Penelitian ini bertujuan untuk untuk mengetahui efek samping obat anti TB (OAT) pada pasien tuberculosis di Puskesmas. Penelitian ini bersifat deskriptif dengan jumlah 35 responden. Metode pengumpulan data menggunakan kuesioner dan dilaksanakan pada tanggal 18 Juni- 18 Juli 2019. Hasil penelitian menunjukkan bahwa 27 responden (77.1\%) mengalami efek samping OAT, sedangkan yang tidak mempunyai keluhan hanya sebanyak 8 responden (22,9\%). Keluhan yang paling dominan dialami pasien TB adalah keluhan kesemutan dan terasa terbakar di kaki sebanyak 13 orang $(37,1 \%)$ dan diikuti keluhan lain berupa tidak nafsu makan sebanyak 6 responden (17.1), nyeri sendi sebanyak 9 responden (25.7), air seni berwarna kemerahan sebanyak 8 responden (22.9), gatal dan kemerahan pada kulit sebanyak 11 responden (31.4), gangguan keseimbangan sebanyak 6 responden (17.1), icterus tanpa penyebab lain sebanyak 4 responden (11.4), gangguan penglihatan sebanyak 6 responden (17.1), purpura dan ranjatan (syok) sebanyak 1 responden(2.9).
\end{abstract}

Kata Kunci $\quad$ : Efek Samping, Obat Anti TB

\section{ABSTRACT}

Tuberculosis (TB) is an infectious disease that must get special treatment with antibiotics given at least 6 months. The use anti-TB drugs with various types of drugs and a long duration can cause complaints of side effects. This study of research to determine the side effects anti-TB drugs in patients who are treating TB treatment at the health center. This research is descriptive with 35 respondents. The data collection method used a questionnaire and was carried out on 18 June-18 July 2019. The results showed that 27 respondents (77.1\%) experienced side effects of anti-TB oabat, while only 8 respondents (22.9\%) had no complaints. The most common complaints experienced by TB sufferers during treatment were complaints of tingling and burning sensation in the legs of 13 people (37.1\%) and followed by other side effects in the form of no appetite as many as 6 respondents (17.1), joint pain as many as 9 respondents (25.7), redness in urine (urine) by 8 respondents (22.9), itching and redness on the skin by 11 respondents (31.4), impaired balance by 6 respondents (17.1), icterus without other causes by 4 respondents (11.4), visual impairment as many as 6 respondents (17.1), purpura and climbing (shock) as much as 1 respondent (2.9).

Keywords: Side Effects, Anti-TB drugs 
Jurnal Keperawatan Abdurrab

Vol 4. No.1, Juli 2020

P-ISSN : 2541-2620
E-ISSN : 2579-8723

Munculnya efek samping obat anti TB

\section{PENDAHULUAN}

Penyakit Tuberkulosis (TB) merupakan penyakit menular yang hingga saat ini masih menjadi permasalahan kesehatan dunia. Berdasarkan laporan World Health Organization (WHO) tahun 2015 , negara Indonesia berada pada peringkat 2 dari 20 negara berada di bawah India dengan persentase kejadian TB sebesar 10.3\%. Pada tahun 2011 WHO menyatakan bahwa penyakit TB setiap tahunnya menyebabkan infeksi sekitar 9.000.000 orang dan membunuh hampir 1.400 .000 orang yang ada di seluruh dunia (Musdalipah, Eny Nurhikma, karmilah, 2018).

Meskipun prevalensi penyakit TB masih tinggi, Indonesia merupakan negara pertama diantara HBCs di Regio Asia Tenggara WHO yang mampu mencapai target global TB untuk melakukan deteksi kasus dan keberhasilan pengobatan pada tahun 2006. Target tersebut yaitu angka penemuan kasus TB $\geq 70 \%$ (Case Detection Rate / CDR) dan angka kesembuhan $\geq 85 \%$ (Sucess Rate/ SR). Namun, CDR dan SR di tingkat provinsi di Indonesia masih bervariasi. Salah satunya Provinsi Riau, CDR TB Paru pada tahun 2012 di provinsi ini adalah 31,7 \% dengan SR 79,20 \% (Ikhwani, 2012).

Salah satu upaya dalam pengendalian penyakit tuberculosis adalah dengan metode DOT's. (Directly Observed Treatment of Short Course) yang telah dicanangkan oleh pemerintah sejak tahun 1999. Strategi DOTs berlangsung hingga saat ini, dilaksanakan secara nasional di seluruh fasilitas kesehatan di Indonesia (Musdalipah, 2018 \& Ikhwani, 2012).

Berdasarkan hasil penelitian oleh Badan Penelitian dan Pengembangan Kesehatan Republik Indonesia, salah satu faktor sehingga rendahnya cakupan angka kesembuhan adalah ketidakpatuhan pada pengobatan penderita TB paru. Hal ini dapat disebabkan oleh efek samping dari obat anti TB sehingga beberapa penderita memilih untuk berhenti mminum obat anti TB karena merasa tidak nyaman pada saat minum obat anti TB (Rahmi, Irvan, \& Ifdelia, 2017). dapat mempengaruhi tingkat morbiditas dan morbilitas penyakit TB. Sebagian besar pasien TB mempunyai keluhan saat meminum obat anti TB pada saat menjalani terapi. Hasil penelitian Sinha et al, 2013 sebanyak 69,01\% pasien mengalami efek samping obat anti TB. Berdasarkan Kemenkes RI pasien TB bisa mengalami efek samping minum obat $\mathrm{TB}$. Efek samping karena OAT dapat berupa keluhan kurang nafsu makan, nausea, muntah, keluhan nyeri abdomen, perasaan pusing, nyeri kepala, gatal-gatal pada kulit, nyeri pada persendian, sensasi kesemutan,., mengalami gangguan penglihatan, gangguan pendengaran serta perubahan warna kemerahan pada urine (Akhmadi, 2017).

Beratnya efek samping OAT yang dialami pasien TB biasanya akan berdampak pada kepatuhan pasien minum obat yang dapat mengakibatkan putus berobat (Sari, 2014 \& Akhmadi, 2017). Hasil wawancara peneliti kepada responden pada saat melakukan survey awal di Puskesmas Harapan Raya Pekanbaru, beberapa responden mengalami keluhan yang bervariasi berupa gatal-gatal, sakit kepala dan mual.

\section{METODE PENELITIAN}

Metode pada penelitian ini menggunakan desain deskriptif dengan melakukan pengambilan sampel data primer dengan menggunakan kuesioner yang di bagikan ke pasien TB di Puskesmas Harapan Raya Pekanbaru. Analisa data penelitian ini menggunakan distribusi frekuensi dengan program SPSS. 
HASIL DAN PEMBAHASAN

Hasil penelitian adalah sebagai berikut:

Tabel 1.1

Distribusi frekuensi lama responden mengalami TB di Puskesmas Harapan Raya Pekanbaru 2019

\begin{tabular}{|c|c|c|c|}
\hline No & $\begin{array}{l}\text { Lama } \\
\text { Sakit }\end{array}$ & Frekuensi & Persentase \\
\hline 1 & $\geq 6$ bulan & 18 & 51.4 \\
\hline 2 & $\leq 6$ Bulan & 17 & 48.6 \\
\hline & Total & 35 & 100 \\
\hline
\end{tabular}

Berdasarkan tabel 1.1 dapat diketahui bahwa responden yang mengalami sakit TB lebih banyak yang sudah lebih dari 6 bulan yaitu sebanyak 18 responden $(51,4 \%)$.

Tabel 1.2

Distribusi frekuensi durasi responden minum obat Anti TB di Puskesmas Harapan Raya Pekanbaru 2019

\begin{tabular}{|c|c|c|c|}
\hline No & Durasi & Frekuensi & Persentase \\
\hline 1 & 1-3 bulan & 10 & 28.6 \\
\hline 2 & 4- 6 bulan & 5 & 14.3 \\
\hline 3 & $\geq 6$ bulan & 20 & 57.1 \\
\hline & Total & 35 & 100 \\
\hline
\end{tabular}

Berdasarkan tabel 1.2 menunjukkan bahwa paling banyak responden telah meminum obat anti TB lebih dari 6 bulan sebanyak 20 responden $(57,1 \%)$.
Tabel 1.3

Distribusi frekuensi keluhan efek samping minum obat anti TB di Puskesmas Harapan Raya Pekanbaru 2019

\begin{tabular}{llll}
\hline No & $\begin{array}{l}\text { Terdapat } \\
\text { keluhan }\end{array}$ & Frekuensi & Persentase \\
&
\end{tabular}

\begin{tabular}{lllll}
\hline 1 & Ada & 27 & 77.1 \\
2 & Tidak ada & $\underline{8}$ & $\underline{22.9}$ \\
\cline { 1 - 2 } & $\underline{\mathbf{3 0 t a l}}$ & $\underline{\mathbf{3 5}}$ & $\underline{\mathbf{1 0 0}}$ \\
\hline
\end{tabular}

Berdasarkan tabel 1.3 terlihat mayoritas responden mengalami keluhan efek samping minum obat anti $\mathrm{TB}$ sebanyak 27 responden (77.1\%), sedangkan yang tidak mempunyai keluhan hanya sebanyak 8 responden $(22,9 \%)$.

\section{Tabel 1.4}

Distribusi frekuensi jenis keluhan efek samping obat anti TB di Puskesmas Harapan Raya Pekanbaru 2019

\begin{tabular}{l|c|c}
\hline \multirow{2}{*}{ Jenis keluhan } & \multicolumn{2}{|c}{ Responses } \\
\cline { 2 - 3 } & $\mathbf{N}$ & $\mathbf{\%}$ \\
\hline $\begin{array}{c}\text { 1. Tidak ada nafsu makan, } \\
\text { mual dan sakit perut }\end{array}$ & 6 & 9.4 \\
\hline 2. Nyeri sendi & 9 & 14.1 \\
\hline $\begin{array}{l}\text { 3. Kesemutan dan terasa } \\
\text { terbakar di kaki }\end{array}$ & 13 & 20.3 \\
\hline $\begin{array}{l}\text { 4. Warna kemerahan pada air } \\
\text { seni (urine) }\end{array}$ & 8 & 12.5 \\
\hline $\begin{array}{l}\text { 5. Gatal dan kemerahan pada } \\
\text { kulit }\end{array}$ & 11 & 17.2 \\
\hline 6. Gangguan keseimbangan & 6 & 9.4 \\
\hline 7. Icterus tanpa penyebab lain & 4 & 6.2 \\
\hline 8. Gangguan penglihatan & 6 & 9.4 \\
\hline 9. Purpura dan ranjatan & 1 & 1.6 \\
\hline Total & $\mathbf{6 4}$ & $\mathbf{1 0 0}$ \\
\hline
\end{tabular}


Jurnal Keperawatan Abdurrab

Vol 4. No.1, Juli 2020

Tabel 1.4 menunjukkan bahwa keluhan efek samping obat anti TB selama pengobatan paling banyak adalah keluhan kesemutan dan terasa terbakar pada area kaki sebanyak 13 responden (37.1\%) dan diikuti dengan keluhan lain berupa anoreksia sebanyak 6 responden (17.1\%), nyeri sendi sebanyak 9 responden $(25.7 \%)$, warna kemerahan pada air seni (urin) sebanyak 8 responden (22.9\%), gatal dan kemerahan pada kulit berjumlah 11 responden (31.4\%), gangguan keseimbangan sebanyak 6 responden $(17,1 \%)$, icterus tanpa penyebab lain sebanyak 4 responden (11.4\%), gangguan penglihatan sebanyak 6 responden (17.1\%), dan purpura dan ranjatan (syok) sebanyak 1 responden $(2.9 \%)$.

Hasil penelitian Musdalipah (2018), memperoleh hasil bahwa efek samping obat anti TB yang paling banyak adalah perasaan mual, muntah dan perubahan warna urin menjadi kemerahan (71,5\%). Efek lain yang lain berupa kurang nafsu makan (38\%), nyeri pada persendian (33\%), keluhan gatalgatal dan kemerahan pada kulit $(28,5 \%)$.

Keluhan rasa mual, anoreksia dan nyeri pada perut dapat disebabkan oleh Rifampisin (R). sedangkan keluhan nyeri pada persendian dapat disebabkan oleh pirazinamid (P), keluhan gatal-gatal dan kesemutan dapat disebabkan oleh Isoniazid (H), keluhan gangguan penglihatan dapat disebabkan oleh etambutol (E), dan keluhan sakit kepala dan pusing dapat disebabkan oleh Streptomisin (S) (Kemenkes RI, 2011).

Reaksi munculnya efek samping OAT dapat dipengaruhi oleh gen dari pasien pada suatu ras tertentu. Ras asia secara genotip tergolong rapid acetylator yang cenderung lebih rentan mengalami hepatotoksik karena isoniazid (Sari et al., 2014).
Efek samping yang OAT yang harus diwaspadai adalah efek hepatotoksik. Hampir semua OAT memiliki efek hepatotoksik kecuali streptomisin ( Yee D, 2003). Kerusakan sel hati dapat terjadi bervariasi dari gejala yang ringan sampai menimbulkan gejala yang serius akibat nekrosis pada sel hati. Pirazinamid yang sering dipakai untuk pengobatan jangka pendek TB paru sering menyebabkan hepatitis. SGOT dan SGPT yang meningkat merupakan tanda gejala awal terjadi kelainan pada hati (Kemenkes RI, 2008) dalam (Sari et al., 2014).

Pada hasil penelitian menunjukkan bahwa mayoritas lama responden minum obat anti TB adalah lebih dari 6 bulan sebanyak 20 responden $(57,1 \%)$ sedangkan 1-3 bulan sebanyak 10 responden $(28,6 \%)$ dan 4-6 bulan sebanyak 5 responden (14,3\%). Hasil penelitian Natalie J, dkk (2016) memperoleh hasil bahwa keluhan efek samping yang dialami pasien TB adalah keluhan pada saluran gastrointestinal, hepatotoksik, perubahan hematologic, gangguan neuropsikiatri, keluhan pada kulit, gangguan neuropati perifer dan terjadi lipodistrofi. Berdasarkan uji statistik, peluang kejadian efek samping lebih besar pada fase lanjutan ( masa pengobatan $>$ dua bulan) dibandingkan fase intensif ( masa pengobatan $\leq$ dua bulan).

Hasil penelitian Pratiwi, Rohmawaty, \& Kulsum, (2018), menunjukkan bahwa efek samping kategori dari OAT banyak dialami pasien di bulan pertama (40\%), dan bulan kedua (40\%). Kombinasi obat isoniazid, rifampisin dan pirazinamid akan menyebabkan peningkatan risiko terjadinya hepatotoksisitas pada dua bulan pertama.

Hasil penelitian Sari et al. (2014), 
Jurnal Keperawatan Abdurrab

Vol 4. No.1, Juli 2020

pada bulan pertama responden sering mengeluh perasaan mual, mengantuk, pusing, gatal ,nyeri dan pegal pada persendian dan mengalami gangguan penglihatan. Pada bulan kedua dan ketiga responden masih memiliki keluhan yang sama dengan bulan pertama, sedangkan pada bulan keempat dan kelima keluhan yang dialami pada bulan keenam keluhan yang dialami responden menurun kembali. Namun peningkatan dan penurunan keluhan ini bervariasi pada masing masing responden.

Bila terjadi keluhan efek samping OAT, tenaga kesehatan sering mengalami kesulitan untuk menentukan obat anti TB mana sebagai penyebab keluhan tersebut. Biasanya keluhan efek samping OAT diatasi dengan pemberian obat-obat simptomatik seperti anti mual, anti muntah, analgetik antipiretik dan vitamin B6. Namun, apabila keluhan efek samping yang dialami tidak hilang, maka perlu dilakukan pertimbangan untuk mengganti dengan obat yang lain (Kemenkes RI, 2011).

\section{KESIMPULAN}

Berdasarkan hasil penelitian yang dilaksanakan tanggal 18 Juni 2019 di Puskesmas Harapan Raya Pekanbaru diperoleh hasil keluhan efek samping obat anti TB yang paling dominan dialami pasien adalah keluhan kesemutan dan terasa terbakar di kaki, kurang nafsu makan, nyeri sendi, warna kemerahan pada urin, rasa gatal dan kemerahan pada kulit, gangguan keseimbangan, icterus tanpa penyebab yang jelas, keluhan berupa gangguan penglihatan, terjadi purpura dan ranjatan.
P-ISSN : 2541-2620

E-ISSN : 2579-8723

\section{DAFTAR PUSTAKA}

Akhmadi, (2017). Monitoring Efek Samping Obat Anti-Tuberkulosis (OAT) Pada Pengobatan Tahap Intensif Penderita TB Paru Di Kota Makassar. Journal of Agromedicine and Medical Sciences Vol. 3 No. 1 (2017).

Djojodibroto, (2009). Ilmu Kesehatan Masyarakat. Jakarta : Rineka Cipta

Ikhwani Aulia, (2015). Peran Keluarga Dalam Meningkatkan Kepatuhan Minum Obat Anti Tuberkulosis Pada Pasien Tuberkulosis Paru Di Wilayah Kerja Puskesmas Harapan Raya Pekanbaru. Pekanbaru : FK volume 2 No.2 Oktober 2015.

Infodatin, (2016). Tuberkulosis,Temukan Obati Sampai Sembuh. Pusat Data Dan Informasi Kementrian Kesehatan RI, 24 maret 2016.

Kemenkes RI, (2009) Pedoman Nasional Pengendalian Tuberkolosis.

Kementrian Kesehatan Republik Bakti Husada : Indonesia Direktorat Jenderal Pengendalian Penyakit Dan Penyehatan Lingkungan. 2011.

Musdalifah, (2018). Efek Samping Obat Anti Tuberkulosis (Oat) Dan Penanganannya Pada Pasien Tuberkulosis (Tb) Di Puskesmas Perumnas Kota Kendari. manuntung : jurnal ilmiah, 4(1), 6773, 2018.

Rahmi, Nitari, (2017). Hubungan Tingkat Kepatuhan Penderita Tuberkulosis Paru, Perilaku Kesehatan, Efek Samping OAT dan Peran PMO pada Pengobatan Fase Intensif di Puskesmas Seberang Padang. Jurnal Kesehatan Andalas. 2017; 6(2) . 
Setiadi, (2007). Konsep Dan Penulisan Riset Keperawatan. Jogjakarta : Graha Ilmu

Soemantri, (2007). Keperawatan Medical Bedah: Asuhan Keperawatan Dengan Gangguan System Pernapasan. Salem Medika : Jakarta Tambunan, Angelina, (2018). Analisis Penatalaksanaan Program Penanggulangan TB Paru dengan Strategi Dots di Puskesmas Belawan Kecamatan Medan Belawan. Universitas Sumatera Utara 